\title{
Indonesia's Role in Fulfilling the Right to Education Elementary and Intermediate in Border Areas
}

\author{
Endah Rantau Itasari ${ }^{1{ }^{*},}$, Dewa Gede Sudika Mangku², Ni Putu Rai Yuliartini ${ }^{2}$, Elly Kristiani \\ Purwendah $^{3}$, Levina Yustitianingtyas ${ }^{4}$, Francisca Romana Harjiyatni ${ }^{5}$ and I Gusti Made \\ Arya Suta Wirawan ${ }^{2}$
}

\author{
${ }^{1}$ Faculty of Law, Universitas Tanjungpura, Jalan Prof. Dr. H. Hadari Nawawi Pontianak, Indonesia \\ ${ }^{2}$ Faculty of Law and Social Sciences, Universitas Pendidikan Ganesha, Jalan Udayana No. 11 Singaraja Bali \\ Indonesia \\ ${ }^{3}$ Faculty of Law, Universitas Wijayakusuma, Jalan Raya Beji Karangsalam Purwokerto Indonesia \\ ${ }^{4}$ Faculty of Law, Universitas Muhammadiyah Surabaya \\ ${ }^{5}$ Faculty of Law, Universitas Janabadra, Jl. Timoho II/40 Yogyakarta Indonesia 55165
}

\begin{abstract}
The role of the state in carrying out educational development and in order to fulfill the right to education, especially primary and secondary education in border areas must be further enhanced. The state must be present among school-age children in border areas by manifesting itself in the form of appropriate and representative school buildings. The state must exist in the form of adequate educational support facilities. The state must be present in the form of teachers and education personnel who are sufficient in number and have competence. The state must be present in the form of budget politics that supports education development in border areas. The state must also be present in a curriculum that suits the needs of school-age children in border areas as well as enhances their national insight.
\end{abstract}

Keyword: Education rights, area, borders.

\section{INTRODUCTION}

A state border area is an area within the territory of a country bordering the territory of another country. State border area in West Kalimantan Province bordering the territory of another country, namely Malaysia (Purwanto, H., \& Mangku, D. G. 2016). The state border area is the territory of Indonesia's sovereignty which lies along the demarcation line of the Malaysian territory which includes five regencies, namely Sambas, Bengkayang, Sanggau, Sintang and Kapuas Hulu Regencies. The fulfillment of primary and secondary education is the government's effort to formulate and implement laws, policies, programs, activities and funding for the teaching and learning process for formal education at kindergarten, elementary, junior high and high school levels in the border areas of Indonesia in West Kalimantan Province. This research will specifically discuss primary and secondary education (Mangku, D. G. S. 2018).

The existence of the right to education, especially primary and secondary education, is undoubtedly present both at the national and international levels.

*Address correspondence to this author at the Universitas Tanjungpura, Indonesia; Tel/Fax: +62 561 753252;

E-mail: endah.rantau.itasari@hukum.untan.ac.id
Particularly in Indonesia, the dynamics of national law politics affect the implementation of the right to education derived from the 1945 Constitution of the Republic of Indonesia (Alfath, TP, et al., 2019). The basic provisions of international human rights law such as in the Universal Declaration on Human Rights (UDHR) 1949, the International Covenant on Economic, Social and Cultural Rights (ICESCR) 1966 and in the Convention on The Rights of The Child 1989 have influenced policy fulfillment of these rights (Hakim, L., \& Sudaryanto, A. 2015).

The preamble to the 1945 Constitution emphasized that one of the objectives of the establishment of the Indonesian state government was "to educate the nation's life". This objective is further formulated through Article 28C paragraph (1) and Article 31 of the 1945 Constitution. This constitutional mandate has been further elaborated in various Indonesian national laws and regulations. The provisions of Law Number 20 of 2003 concerning the National Education System were made as lex specialis from the provisions of the Articles in the Indonesian Constitution. In connection with the ICESCR, Indonesia has ratified the covenant on September 30, 2005 through Law Number 11 of 2005 concerning the Ratification of the International Covenant on Economic, Social and Cultural Rights (Adi, E. A. P, 2018). 
The ICESCR regulates itself the right to education in Articles 13 and 14. Based on these provisions, Indonesia is obliged to fulfill the right to education, in particular the right to primary and secondary education to the maximum extent possible based on the maximum available resources (Beiter, K. D.2005). Since it was ratified in 2005, over a period of 12 years, many laws, policies, programs, policies and funding have been created and implemented. However, the criteria for fulfilling the right to education in the ICESCR have not been actually implemented in the field. There is very little stagnation of change in the formation and implementation of laws, policies, programs, activities and education funding, especially in these border areas (Veriava, F., \& Paterson, K.2020).

The essence of the right to education at the level of primary and secondary education is a certain condition that must be created by a ratifying state. The substantive aspects of education and managerial delivery of education are basic elements in Article 13 of the ICESCR (Aubry, S., \& Dorsi, D.2016). This element requires the state to provide basic education for everyone (education for all). The aspects of the availability and convenience of educational facilities and infrastructure, and the aspects of acceptance and adaptability are legal segments (indicators) that must be conditioned for their fulfillment in stages (Tomaševski, K.2005). Particular attention and emphasis should be paid to specific conditions or situations in certain areas. Thus, the fulfillment of primary and secondary education includes all elements of education. Indonesia as a party to the ICESCR is bound to implement these provisions based on the international obligations contained therein (Thapliyal, N. 2012).

The implementation of the fulfillment of the right to primary and secondary education in the border area of Indonesia and Malaysia in West Kalimantan Province has special problems, obstacles and challenges (Itasari, E. R.2019). All of these things are due to certain situations and conditions that exist in the border area. These situations and conditions became 11 finding clusters of problems with the fulfillment of the right to education by the Ministry of Education and Culture of the Republic of Indonesia in 2011. One of these clusters of problems is the emergence of "areas with no desire to go to school" at the primary and secondary levels in state border areas in West Kalimantan Province, particularly in the areas of Sambas, Bengkayang, Sanggau, Sintang and Kapuas Hulu Regencies. This problem does not occur in other areas such as the border area between Indonesia and Papua New Guinea (PNG) and the Democratic Republic of Timor Leste (RDTL). With the existence of problems such as the above, this research will discuss about how the role of the Indonesian state in providing fulfillment of basic and secondary education rights in border areas for its citizens.

\section{RESEARCH METHOD}

The purpose of the research entitled Indonesia's Role in Fulfilling the Right to Education Basic and Intermediate in the Border Area, how Indonesia provides educational services to its citizens in border areas and fulfills all the needs of all its citizens without exception, this is done to guarantee the constitutional rights of its citizens and this is the responsibility of a country and this has Outlined in the constitution of the Indonesian nation, as well as to obtain an overview and analyze the suitability of laws, policies, programs, activities and funding for primary and secondary education both vertically and horizontally. This is intended as a manifestation of the implementation of the obligation to fulfill the rights to primary and secondary education in accordance with the provisions of the International Covenant on Economic, Social and Cultural Rights, especially in the border area of Indonesia and Malaysia in the West Kalimantan Province.

\section{LITERATUR REVIEW}

\subsection{State Border Area}

The state border area is a National Strategic Area according to the provisions of Law Number 26 of 2007 concerning Spatial Planning. The implication of determining the National Strategic Area is that policies, programs and funding for the development of border areas are the main responsibility of the Central Government. Presidential Regulation Number 44 of 2017 concerning Amendments to Presidential Regulation Number 12 of 2010 concerning the National Agency for Border Management affirms that the task and authority for managing border areas lies with the Central Government. Based on the Regulation of the Minister of Home Affairs Number 140 of 2017 concerning the Formation of Border Management Bodies in the Region, the border management institution involves the local government with the assumption that the government is an extension of the central government in the regions. Coordination and supervision are the duties of the Coordinating Minister 
for Law and Security. Although this determination is based on the aspect of defense and security, this status requires the state to be present in determining, coordinating and implementing policies, programs and funding for the development of border areas (Hadi, 2010).

A border is a demarcation line between two sovereign nations. The border area is the territory of state sovereignty which may consist of land, sea and air dimensions. In principle, the border area refers to the land or sea area that connects the territory of a country with other countries. This area is an area that plays an important role in the political competition between two different countries which limit two different jurisdictions. Region differs from the region. According to the provisions of Law Number 43 of 2008 concerning State Territory, regions and regions have different meaning areas and scopes.

Territory is one of the elements of a state which is a unitary land area, inland waters, archipelagic waters, and territorial sea along with its marine basins and the land under it, as well as the natural resources contained therein (Itasari, E. R. 2020). The area is part of the country's territory which is located on the inner side along the borders of the Indonesian state and other countries. The state border area in West Kalimantan Province is divided administratively into five districts, namely Sambas, Bengkayang, Sanggau, Sintang and Kapuas Hulu District. The interior of the area stretches to the east, consecutively covering the provinces of East Kalimantan and North Kalimantan (Dubner, B. H.2013).

The government has issued many policies and programs in border areas with various approaches (Dale, R. 2005).). The security approach, the environmental approach and the welfare approach characterize the management of the border between Indonesia and neighboring countries, especially on the Island of Kalimantan: West, East and North Kalimantan. integrated by integrating all related sectors. One of the policies of the New Order government in dealing with border problems, namely using a security approach alone by ignoring the welfare approach so that many residents in border areas have economic dependence on neighboring countries (Ball, S. J. 2009). On the other hand, the regional autonomy regime has also become one of the obstacles to the realization of community development at the border due to the existence of regional autonomy legal instruments that often overlap and are weak in its implementation, providing guarantees for the protection and fulfillment of the rights to education, health and housing for people in border areas so that a number of villages underdeveloped status in border areas are increasingly not touched by policies that are oriented towards community rights, particularly the right to education and health (Green, A. 1997).

\subsection{Determinants of Fulfillment of Primary and Secondary Education in Border Areas}

The factual conditions and determining factors for the fulfillment of the right to primary and secondary education are a re-actualization of state sovereignty. State sovereignty is the result of a reflection, abstraction and contemplation of the ability of a country to maintain and maintain its existence in international law and relations. State sovereignty builds arguments about the laws and legal systems that apply in a country, including in fulfilling the right to education in Indonesia. State sovereignty is a legal prescription to create, implement and enforce the law on people, objects and legal actions in the field of education following applicable standards and laws. Legal rights and obligations are formed and interact with each other in the legal system of a country so that the factual conditions and determinants of the right to primary and secondary education in border areas are the sovereignty of the Indonesian state itself following the international agenda accepted by Indonesia in the field of education (Kennedy, P. S. J., et al., 2018).

The concept of state sovereignty is one of the most important elements in determining rights and obligations in international law. The concept of state sovereignty is a general statement that contains the objectivity and integrity of an answer about what sovereignty is. In addition, state sovereignty answers the question of how sovereignty affects the application of law in the internal and external context in international relations. In addition, the answer to the question of why state sovereignty is important in the international legal system and the international and regional human rights protection legal system represents and sharpens the essence of the concept of state sovereignty.

State sovereignty in international law builds a standard identity for international legal subjects. The subjects of international law are entities that have and cancarry out and are burdened with obligations that are regulated and determined by international law because they have the personality of international law. The 
personality of the law makes them subject to rights and obligations linearly and imperatively. The imperative nature is marked by the ability of the international law subjects to carry out and be burdened with certain legal acts, both in the active and passive meaning, especially by Indonesia when it has ratified the Covenant on Economic, Social and Cultural Rights and the Convention on the Rights of the Child (Werang, B. R., et al. 2014).

The sovereignty of the Indonesian state has external and internal dimensions for a country. Both scopes are functional. The functionality of state sovereignty is very determinative in the application of rights and obligations held by the state. Jurisdiction is a direct derivative of the concept of state sovereignty. One example of the application of this concept is state sovereignty over its territorial jurisdiction. Territorial jurisdiction is a derivative of the concept of absolute state sovereignty in determining education legislation, policies, programs, activities and funding (Defit, S., \& Dewi, Y. N.2019).

Jurisdiction is the ability to create, implement and enforce the enforcement of state authority on people, objects and actions within the jurisdiction or within its territory. State authority over territorial areas depends on the international legal regime that regulates it, such as jurisdiction over land, sea and air areas. The concept of state sovereignty over territory gives rise to sovereign rights and sovereign rights which have different legal dimensions. State sovereignty is a source of dispute as well as a source of strength for a country. The concept of state sovereignty in an internal dimension can be found in its regulation in the Indonesian legal system about its rights and obligations.

In the context of international human rights studies, state sovereignty is an objective and integrative statement of truth (righteous) and the fulfillment of the law (entitlement). The concept of state sovereignty is the result of a reflection, abstraction and contemplation of the truth and fulfillment of the law. The sovereignty of the state builds arguments about the laws and legal systems that apply in a country that rests on the values of universal human rights and basic human freedoms. State sovereignty is a legal prescription to create, implement and enforce the law on people, objects and legal actions. This prescription gave rise to an agreement between rights holders and rights enjoyers. The truth and fulfillment of the law become the standardization of state behavior towards its citizens or groups of individuals within the country in the framework of protecting, fulfilling and advancing human rights in its territory or jurisdiction, including the right to primary and secondary education in the border areas of the Indonesian state.

This concept of state sovereignty has inspired the formation of legal obligations for the state to respect, to fulfill and to protect the human rights and basic freedoms of its citizens. When their human rights are fulfilled, protected and respected by the state, citizens have individual and collective legal expectations based on equality, freedom and integrity. This legal expectation is the basis for the formation of the ideals or basic goals of a sovereign state.

\section{RESEARCH METHODS}

This research is an empirical normative legal research to gain excellence and academic truth in fulfilling international human rights obligations that Indonesia has received, especially in the field of education based on the provisions of the ICESCR (Lamont, 2009). This study aims to reveal the truth systematically, methodologically, and consistently to the fulfillment of the right to education by the Indonesian state after ratifying international provisions from 2005 to 2018. Analysis and construction of primary data and secondary legal materials determine the empirical normative type of this research.

Searching for new things through research in order to find, develop, and test the truth of knowledge characterizes the novelty of law in this study. The search through this research certainly fulfills scientific principles to find answers to a matter, problem, situation, fact or phenomenon faced by the government in fulfilling primary and secondary education in the border area of the state in West Kalimantan Province. This truth-seeking has been carried out using the scientific method to find the truth based on logical and systematic considerations. Besides empirical normative, this research is evaluative and prescriptive research. It is said that the research is evaluative because this research provides an in-depth analysis of the fulfillment of human rights concerning education in the border areas of Indonesia and Malaysia, especially in West Kalimantan Province after Indonesia was bound by international legal provisions, namely the Covenant on Economic, Social and Cultural Rights, 1966. The prescriptive nature of this research is seen in terms of that this research also provides the right solution based on the principles of international law and 
human rights law, especially in the field of education, to overcome obstacles in fulfilling the human rights to education in the regions and border areas between Indonesia and Malaysia.

Data analysis is a description of the methods of analysis, namely how to use the collected data to be used in solving research problems. Primary and secondary data obtained from the results of field research and literature are analyzed and studied for their legal relevance and used to describe the conceptions and theories used in this study. The data in this study were analyzed qualitatively, which means that this analysis seeks to find the truth based on the value or quality of the data obtained, namely the suitability of indicators for the fulfillment of the right to education in the state border area in West Kalimantan Province.

To carry out this qualitative analysis, the researcher conducted an analysis through the following stages, namely: (1). Collecting data grouped according to the object or variable in the study; (2). Sorting and processing data regarding laws, policies, programs, activities and funding for primary and secondary education in border areas; (3). Evaluating data by quantification and prescription according to their relevance, (4). Establish conclusions and recommendations if needed between 2005 and 2017 .

\section{DISCUSSION}

\subsection{Indonesia's Role in Fulfilling the Right to Education Elementary and Intermediate in Border Areas}

Initially, education was the responsibility of the community and the population as a form of transferring technical skills needed to carry out tasks in daily life, transferring religious, philosophical, social and cultural values from the community and population to the younger generation (Jens Bartelson, 2006). It was only after the emergence of the modern state that education was considered a public problem whose fulfillment was a state obligation. The view that education is a state obligation is shared by both the liberal concept of human rights and the concept of human rights socialism. Because of the liberal concept of human rights, the state's obligation to fulfill the right to education is placed alongside the obligations that parents have in providing education for their children.

The state's obligation, in this case, is more on the aspect of ensuring that every child receives an adequate education through formal arrangements for the school curriculum. Meanwhile, in the view of socialism, the fulfillment of the right to education is one of the main tasks of the state. The considerable influence of the ideology of socialism on the thought of Indonesia's founding fathers has led to this view being accepted and formulated as one of the goals of the Indonesian state as contained in the Preamble to the 1945 Constitution. ICESCR itself, in Article 2 paragraph (1), has provided outline steps for which must be pursued by a state party in fulfilling its obligations to fulfill economic, social and cultural rights, including the right to education: "every state party ... promises to take steps, either alone or through the assistance of international cooperation, to progressively achieve the full realization of the rights recognized by the present Covenant, including by taking legislative measures".

From the provisions in Article 2 paragraph (1) of the ICESCR, there are two characteristics, namely: first, the emphasis on state obligations rather than the formula "everyone has the right to ..." or "everyone may not do ...". Which liability rests on the available resources. Second, fulfillment progressively (gradually). The provisions of Article 2 paragraph (1) require all States parties to start immediately to take steps so that all people can fully enjoy all the rights contained in the Covenant. However, the component of "the obligation to achieve in stages" (progressive realization) as formulated in the Covenant is often misunderstood that the fulfillment of economic, social and cultural rights will be realized after or when a country has reached a certain level of economic development.

Whereas what is meant by this formulation is obliging all participating countries to realize economic, social and cultural rights, regardless of the level of economic development or the level of national wealth. This means that the provisions formulated in the Covenant cannot be interpreted as allowing states to postpone their efforts indefinitely in order to guarantee the realization of the rights outlined in the Covenant. In fact, this formulation obliges the state to move as quickly as possible towards the fulfillment of economic, social and cultural rights. The obligation of participating countries to realize eco-social rights, therefore, does not depend on the level of resource availability and therefore all available resources must be used in the most effective way for the realization of rights.

To ensure the fulfillment of people's needs for proper education, the state has an obligation to ensure the provision of an adequate education system and 
curriculum, provision of scholarships, provision of adequate facilities and infrastructure, improving the quality of teaching staff, both teachers and lecturers in tertiary institutions. Because according to the spirit of the ICESCR, the education system established by the government must be able to reach all citizens, be freely accessible without discrimination and be economically and psychologically acceptable, and be able to adapt to the times. According to the Committee, the meaning of the "obligations" of states parties to the ICESCR, as set out in General Comment No. 11 is: "to highlight the fact that neither parents, nor guardians, nor the state are entitled to treat the optional the decision as to whether the child should access to primary education. Similarly, the prohibition of gender discrimination in access to education, required also by articles 2 and 3 of the Covenant, is further underlined by this requirement. It should be emphasised, however, that the education offered must be adequate in quality, relevant to the child and must promote the realisation of the child's other rights.

In the Preamble to the 1945 Constitution it is stated that one of the goals of the state is to educate the life of the nation, and therefore every citizen of the Republic of Indonesia has the right to obtain an equal and quality education according to his interests and talents regardless of social status, ethnicity and gender so that as a member of society will have affection, intelligence and skills that will be useful for recognizing and dealing with problems themselves and their environment.

Improving the quality and access to learning in border areas is an important part of the national defense system. The real defense system is not only in the form of military strength, but also comes from diplomacy and cultural strength. This cultural strength will emerge if humans are able to recognize, understand and feel the richness of the environment, which is supported by a learning process as developed in local wisdom. Improving the quality of education at the border will also be one of the strongholds to strengthen Indonesia's national defense system. Improving the quality of education at the border is an important step to strengthen the national defense system in the nation's front porch through education and culture. Increasing access to education at the border can also erase the stigma of a national political gap regarding increasing resources and infrastructure; as well as making residents in border areas feel part of the Unitary State of the Republic of Indonesia.
The role of the state in carrying out educational development and to fulfill the right to education, especially primary and secondary education in border areas must be further enhanced. The state must be present among school-age children in border areas by manifesting itself in the form of appropriate and representative school buildings. The state must exist in the form of adequate educational support facilities. The state must be present in the form of sufficient and competent teachers and educational personnel. The state must be present in the form of budget politics that supports education development in border areas. The state must also be present in a curriculum that suits the needs of school-age children in border areas as well as enhances their national insight (Kalantry, S., et al. 2010).

The state is the fulfillment of human rights (duty bearer). After the ratification of the ICESCR, the Government through Article 31 of the 1945 Constitution guarantees equal rights and obligations for all citizens to obtain education. As a member of UNESCO, Indonesia has also ratified the Education For All Policy which was agreed upon in Dakkar, Senegal. Some of the contents of the agreement relating to education and gender equality are: (1). Ensure that by 2019 all children, especially girls, children in difficult circumstances and those belonging to ethnic minorities have access to complete free and compulsory basic education of good quality; (2). Achieve a $50 \%$ improvement in adult literacy rates by 2019 , particularly for women and equitable access to basic, sustainable education for all adults; and (3).

Eliminate gender disparities in primary and secondary education by 2019 with a focus on ensuring women full access and equal achievement in quality basic education. Indonesia has also ratified the Convention on the Rights of the Child (CRC). In the provisions contained in the CRC, participating countries (including Indonesia) recognize the right of the child to education and aim to achieve this right gradually and based on equal opportunities, in particular: (1). Make education compulsory and available free of charge to all; (2). Encourage the development of different forms of secondary, general and vocational education, accessible to every child, the adoption of free education and offering financial assistance when needed; (3). Make higher education compulsory for all children based on the abilities of any appropriate means; (4). Making educational information; and (5). Decreased dropout rates (Article 28 of the Convention on the Rights of the Child). 


\section{CONCLUSION}

The government has gradually fulfilled the rights to primary and secondary education in the border areas in West Kalimantan Province from 2005 to 2017. The fulfillment of the right to primary and secondary education in these border areas has become a proof of Indonesia's compliance with the ICESCR and international human rights norms that have been accepted by Indonesia. The conformity factor has been endeavored to fulfill according to international provisions or standards in the Covenant on Economic, Social and Cultural Rights. The stages of fulfillment can be seen from the aspects of compliance with the rules and implementation of the rules with the provisions of the Covenant, namely increasing the availability, accessibility, acceptability and conformity of laws, policies, programs, activities and funding for primary and secondary education. The six indicators that have been implemented in determining the relevance of the aforementioned conformity aspects are based on the actual conditions in the border area of the country. These six indicators are characteristics or elements of legitimate contestation of efforts to fulfill the rights of primary and secondary education in border areas in five districts: Sambas, Bengkayang, Sanggau, Sintang and Kapuas Hulu districts. They are (1). increase in human resources, (2). improvement of infrastructure, (3). transparency and accountability of financial management, (4). academic services, (5). preparation of educational programs, and (6). the relationship between the school institution and the community. The six indicators place the contestation of human rights standards in actual reality on the normative provisions contained in the Convention.

\section{SUGGESTIONS}

The standard of fulfilling the rights to primary and secondary education in border areas needs to be studied as a measure of fulfillment of obligations based on the stages and achievement of results. The reality in the field greatly determines the accountability of these indicators following the conditions and situations in the field which are certainly different from one another, such as urban areas which will certainly be different from rural areas. This study is directed at the legal function of indicators of fulfilling economic, social and cultural rights in the context and perspective of developing countries. This contextuality will produce patterns and trends that are different from the criteria for developed countries and poor countries.

\section{ACKNOWLEDGEMENTS}

We would like to thank Universitas Tanjungpura Pontianak and Universitas Pendidikan Ganesha Singaraja Bali who have allowed us to conduct research related to Indonesia's role in fulfilling education rights Elementary and Intermediate in Border Areas.

\section{REFERENCES}

Adi, E. A. P., Handayani, I. G. A. K. R., \& Supanto, S. (2018). The 1945 Constitution Of The Republic Of Indonesia: The Basis Of The Highest Normative Arrangement Of Mass Organizations In Indonesia. The 4th International and Call for Paper, 1(1).

Alfath, T. P., Pudjiastuti, L., \& Sunyowati, D. (2019, October). The Legal Framework of Green Governance in Archipelagic State Based on Constitution of The Republic of Indonesia. In 3rd International Conference on Globalization of Law and Local Wisdom (ICGLOW 2019). Atlantis Press. https://doi.org/10.2991/icglow-19.2019.9

Asbjorn Eide, Catarina Krause, Allan Rosas, 1995, Economic, Social and Cultural Rights, A Textbook, Martinus Nijhoff, Dordrecht, p. 390.

Aubry, S., \& Dorsi, D. (2016). Towards a human rights framework to advance the debate on the role of private actors in education. Oxford Review of Education, 42(5), 612-628. https://doi.org/10.1080/03054985.2016.1224301

Ball, S. J. (2009). Privatising education, privatising education policy, privatising educational research: Network governance and the 'competition state'. Journal of education policy, 24(1), 8399

https://doi.org/10.1080/02680930802419474

Beiter, K. D. (2005). The protection of the right to education by international law: Including a systematic analysis of article 13 of the International Covenant on Economic, Social and Cultural Rights. Brill. https://doi.org/10.1163/ej.9789004147041.i-738

Dale, R. (2005). Globalisation, knowledge economy and comparative education. Comparative education, 41(2), 117-149. https://doi.org/10.1080/03050060500150906

Defit, S., \& Dewi, Y. N. (2019, August). Effectiveness of the Indonesian literacy school program in improving the quality of basic education for marginal communities in the Indonesian border area. In IOP Conference Series: Earth and Environmental Science (Vol. 314, No. 1, p. 012043). IOP Publishing. https://doi.org/10.1088/1755-1315/314/1/012043

Dubner, B. H. (2013). The law of territorial waters of mid-ocean archipelagos and archipelagic states. Springer.

Green, A. (1997). Education, globalization and the nation state. In Education, globalization and the nation state (pp. 130-186). Palgrave Macmillan, London. https://doi.org/10.1057/9780230371132_8

Hakim, L., \& Sudaryanto, A. (2015). An Institutionalization of the State Commission as a State Institutions on the Basis of the 1945 Constitution of the Republic of Indonesia. JL Pol'y \& Globalization, 33, 77.

Human Rights Committee, General Comment 3, Article 2, para 1; Theodore Meron, 1995, "Extraterritoriality of Human Rights Treaties", 89 American Journal of International Law 78, p. 81; and the Delia Saldias de Lopez v Uruguay Case, Communication No. 52/1979 (29 July 1981) UN Doc CCPR/C/OP/1, 88 (1984) to the Coard et all v United States case, Case 10.951, Report No. 109/99, 29 September 1999. 
Itasari, E. R. (2019). Fulfillment Of Education Rights In The Border Areas Of Indonesia And Malaysia. Ganesha Law Review, 1(1), 1-13. https://doi.org/10.23887/glr.v1i1.14

Itasari, E. R. (2020). Border Management Between Indonesia And Malaysia In Increasing The Economy In Both Border Areas. Jurnal Komunikasi Hukum (JKH), 6(1), 219-227. https://doi.org/10.23887/jkh.v6i1.23473

Jack Goldsmith and Dary Levinson, 2009, "Law for States: International Law, Constitutional Law, Public Law", Harvard Law Review, Vol. 122 No. 7, p.1845

Jens Bartelson, 2006, 'The Concept of Sovereignty Revisited', 17 The European Journal of International Law, Vol.17 hlm. 367463. https://doi.org/10.1093/ejil/chl006

Janice E Thomson, 1995, 'State Sovereignty in International Relations: Bridging the Gap between Theory and Empirical Research', International Studies Quarterly, Vol..39, hlm 213278 .

dan Hedrik Spruyt, 1994, The Sovereign State and its Competitors: An Analysis of Systems Change, Princeton University Press, hlm 56. https://doi.org/10.2307/2600847

Kalantry, S., Getgen, J. E., \& Koh, S. A. (2010). Enhancing enforcement of economic, social, and cultural rights using indicators: A focus on the right to education in the ICESCR. Hum. Rts. Q., 32, 253.

https://doi.org/10.1353/hrq.0.0144

Kennedy, P. S. J., Tobing, S. J. L., Heatubun, A. B., \& Toruan, R. L. (2018, September). Strategic Issues of Indonesian Border Area Development based on The Master Plan 2015-2019. In PROCEEDINGS (Vol. 1, No. 1).

Klaus Dieter Beiter, 2005, The Protection of the Right to Education by International Law, Martinus Nijhoff Publisher, hlm. 1-10.

M. Freeman, 1992, “The Limits of Children's Rights", The Ideologies of Children's Rights, p. 30- 31.

Malik Faissal et al. (2021), Legal Protection for People with Disabilities in the Perspective of Human Rights in Indonesia, International Journal of Criminology and Sociology, Volume 10.

https://doi.org/10.6000/1929-4409.2021.10.62

Mangku Dewa Gede Sudika et al. (2020), Compensation for Oil Pollution Due to Tanker Accidents in the Indonesian Legal System in a Justice Value Perspective, International Journal of Criminology and Sociology, Volume 9. https://doi.org/10.6000/1929-4409.2020.09.63

Mangku, D. G. S. (2018). Legal Implementation On Land Border Management Between Indonesia And Papua New Guinea According to Stephen B. Jones Theory. Veteran Law Review, 1(1), 72-86. https://doi.org/10.35586/velrev.v1i1.393

Michele Lamont, 2009, How Professors Think, Inside the Curious World of Academic Judgement, Harvard University Press, p. 3 https://doi.org/10.4159/9780674054158
Nazifah et al. (2021), Fulfillment of Labor Rights for Persons with Disabilities in Indonesia, International Journal of Criminology and Sociology, Volume 10. https://doi.org/10.6000/1929-4409.2021.10.33

Purwanto, H., \& Mangku, D. G. (2016). Legal Instrument of the Republic of Indonesia on Border Management Using the Perspective of Archipelagic State. International Journal of Business, Economics and Law, 11(4).

Purwendah Elly Kristianti and Mangku Dewa Gede Sudika (2021), Implementation of Compensation for Oil Pollution by Tanker Ships in the Indonesian Legal System, International Journal of Criminology and Sociology, Volume 9. https://doi.org/10.6000/1929-4409.2020.09.63

Riwanto Tirtosudarmo, 2004, Wilayah Perbatasan dan Tantagan Indonesia Abad ke-21: Sebuah Pengantar, dalam Riwanto Tirtosudarmo dan John B, 2004, Dari Entikong Sampai Nunukan, Dinamika Perbatasan Kalimantan-MalaysiaTimur (Serawak-Sabah), Penerbit Sinar Harapan, Jakarta, p. 2-6.

Santos Pais, 2000, "A Human Rights Conceptual Framework for Children's Rights", UNICEF Innovative Essay No.9, p. 5.

Suprayoga Hadi, 2010, Program Pembangunan Kawasan Perbatasan, Paper Bappenas, p., 1-3.

Thapliyal, N. (2012). Unacknowledged rights and unmet obligations: An analysis of the 2009 Indian Right to Education Act. AsiaPacific Journal on Human Rights and the Law, 13(1), 65-90. https://doi.org/10.1163/138819012X13323234709820

Tomaševski, K. (2005). Has the right to education a future within the United Nations? A behind-the-scenes account by the Special Rapporteur on the Right to Education 1998-2004. Human Rights Law Review, 5(2), 205-237. https://doi.org/10.1093/hrlr/ngi014

UN Committee on Economic, Social and Cultural Rights, 1999, Plans of Action for Primary Education; General Comment No. 11 (Art. 14 of the International Covenant on Economic, Social and Cultural Rights).

Veriava, F., \& Paterson, K. (2020). The right to education. In Research Handbook on Economic, Social and Cultural Rights as Human Rights. Edward Elgar Publishing. https://doi.org/10.4337/9781788974172.00015

Werang, B. R., Betaubun, M., \& Leba, S. M. R. (2014). Factors Affecting The Low Quality of Graduates in East Indonesia Border Area (Case Study at State Senior High Schools in Merauke Regency, Papua, Indonesia). International Journal of Education and Research, 2(4), 187-196.

Yuliartini Ni Putu and Mangku Dewa Gede Sudika (2020), Legal Protection for Women Victims of Trafficking in Indonesia in an International Human Rights Perspective, International Journal of Criminology and Sociology, Volume 9. https://doi.org/10.6000/1929-4409.2020.09.160

(C) 2021 Itasari et al.; Licensee Lifescience Global.

This is an open access article licensed under the terms of the Creative Commons Attribution Non-Commercial License (http://creativecommons.org/licenses/by-nc/3.0/) which permits unrestricted, non-commercial use, distribution and reproduction in any medium, provided the work is properly cited. 